\title{
The Relationship Between Corporate Governance and Financial Performance of Small Corporations in Australia
}

\author{
Yongqiang Li, Anona Armstrong and Andrew Clarke \\ Victoria University, Australia
}

\begin{abstract}
This paper examines a widely explored but yet to be confirmed relationship between two latent constructs corporate governance and financial performance of small corporations in Australia. Prior studies have either focused on larger organisations or isolated corporate governance mechanisms in small firms. However, few have examined how corporate governance mechanisms, as a bundle, relate to small corporations. This study fills this gap by empirically analysing the aforementioned relationship using Structural Equation Modelling (SEM). Based on 387 responses from small corporations, the results show that corporate governance bundles measured by the extant literature, has a negative impact on the financial performance of small corporations. The result calls for a stakeholder approach to the governance needs of small corporations.
\end{abstract}

\section{Keywords:}

Corporate governance, financial performance, small corporations, structural equation modelling (SEM)

\section{INTRODUCTION}

Small corporations are the backbone of the Australian economy. Various studies have explored corporate governance as it applies to larger organisations. Few studies, however, have examined how corporate governance relates to small corporations, who are losers in the "corporate governance reform competition", given their resource constraints and failing to put these matters on their strategic agenda (Audretsch and Lehmann 2011).

\section{Definition of corporate governance}

From the Stakeholder Theory perspective, Du Plessis, Bagaric et al. (2010) suggested that the ultimate

Copyright (C) 2014 Victoria University. This document has been published as part of the Journal of Business Systems, Governance and Ethics in both online and print formats. Educational and non-profit institutions are granted a nonexclusive licence to utilise this document in whole or in part for personal or classroom use without fee, provided that correct attribution and citation are made and this copyright statement is reproduced. Any other usage is prohibited without the express permission of the publisher. goal for corporate governance should be toward the optimisation of efficiency and productivity, hence define corproate governance as:

The system of regulating and overseeing corporate conduct and of balancing the interests of all internal stakeholders and other parties (external stakeholders, governments and local communities ...) who can be affected by the corporation's conduct, 
in order to ensure responsible behaviour by corporations and to achieve the maximum level of efficiency and profitability for a corporation (Du Plessis, Bagaric et al. 2010, p. 10).

\section{Definition of a small corporation}

Small corporations are those with less than 50 shareholders and which meet at least two of the following criteria: they have consolidated revenue of less than $\$ 25$ million per year, gross assets of less than $\$ 12.5$ million, and fewer than 50 full-time employees. This definition derives from s $45 \mathrm{~A}(2)$ Corporations Act 2001 (Cth) (Corporations Act 2001 (Cth) s 45 2001). Under this definition, 'small corporations' make up the vast majority of the Australian market - some 1.38 million companies and are vitally important in economic, social and cultural contexts. They employ more than five million members of the Australian workforce (Armstrong, Li and Clarke et al. 2011).

There is a dearth of evidence on the relationship between corporate governance and financial performance of small corporations in Australia, mainly due to the lack of data and low interest in research involvement from the small corporations. Only in recent years have researchers in the field started to explore the governance issues facing small corporations in North America and Europe. Moreover, existing empirical studies have mainly focused on isolated governance mechanisms, while the treatment of corporate governance mechanisms as a bundle has been ignored (Clarke and Branson 2012).

Corporate governance theorists have made significant efforts toward explaining the performance implications of corporate governance in small corporations (Audretsch and Lehmann 2011). Little empirical work has been done, however, to simultaneously operationalise the corporate governance and financial performance constructs with the purpose of establishing the corporate governance mechanisms that fit small corporations in Australia. This research seeks to contribute to our understanding of the fit between these critical constructs. Hence the research question is:

RQ: what is the relationship, if there is any, between corporate governance and financial performance of small corporations in Australia?

The rest of the paper proceeds as follows, Section Two developed the hypotheses based on Agency Theory and Stakeholder Theory. Section Three outlined the details of the method. Section Four reports the results, followed by Discussion in Section Five. Section Six concludes.

\section{THEORY DEVELOPMENT AND HYPOTHESIS}

\section{Relevance of corporate governance to small corporations}

Corporate governance is an established and well-studied subject in Economics, Finance, Accounting, Management and Law (Audretsch and Lehmann 2011). Excellent surveys of the literature on corporate governance of large corporations can be found in Bebchuk and WeIsbach (2010) and Brown, Beekes et al. (2011). These reviews support the contention that, up to now, corporate governance research has mainly been dedicated to and concerned with the traditional American corporations that have thousands of employees and are publicly traded on stock exchanges with the free float of shares and shareholders holding a small fraction of equities in the firm. In contrast, evidence on corporate governance is scarce in non-listed small corporations.

The literature shows extensive research on the efficiency of a corporate board as a central institution of internal governance in large corporations (Audretsch and Lehmann 2011). The focus of interest on small firms is still emerging (Arosa, et al. 2012). However, the literature also identifies differences and similarities in corporate governance for boards in both large and small firms (Machold et al. 2011).

Agency Theory argues that corporate governance mainly deals with three types of conflicts between: 
(1) shareholders and managers; (2) controlling shareholders and minority shareholders; and (3) shareholders and non-shareholding stakeholders (Davies 2000). The governance problems of large corporations mainly arise from the separation of ownership and control in different contractual arrangements. However, unlike their large counterparts, ownership and control are normally concentrated in small firms (Uhlaner et al. 2007). For example, the founding owner of a firm is also the manager. Therefore, the disparity between ownership and managerial self-interest may be relatively smaller in the small firms.

While Agency Theory may be relevant to small firms, the literature argues that the decision-making and control structure is less complex and less diffused in small firms. Thus, the monitoring role of boards is diminished (Arosa, et al. 2012). On the other hand, a firm's interests may change the board's role in small firms (Pugliese and Wenstøp 2007).

The content of board tasks may vary between small and large firms (Zahra and Pearce Ii 1989). Consequently, boards may also assume other roles, including supervisory, advisory and networking. In addition, small business owners are more concerned with firm survival, growth rate, family welfare, succession plan, personal status and long-term financial returns. Furthermore, the impact of founding managers/ entrepreneurs on boards of small firms may be greater than that of their larger counterparts (Arthurs et al. 2009).

Small firms' demand for corporate governance has been constrained by their resource constraints. Small firms do not have the luxury of hiring in-house experts. Large corporations, however, benefit from corporate governance in the forms of value creation, cost minimisation and efficiency improvement, while small firms are disadvantaged (Clarke, 2006).

The number of shareholders in small firms is limited. Hence, the second type of conflict - the interest disparity between controlling shareholders and minority shareholders is not a main concern except for the existence of block-holdings. Thus, a main task for corporate governance in small firms is to address the third type of conflicts - the interest alignment between shareholders and shareholding stakeholders (McCahery and Vermeulen, 2010).

Contingency Theory argues that the proper design of corporate governance has to consider environmental factors, for example, institutional environment and ownership characteristics (Huse, 2005). Though existing research and practice is highly concentrated on the corporate governance of listed companies, external stakeholders (such as customers, lenders, insurance companies and equity investors) increasingly require non-listed companied to adopt the corporate governance rules and principles of listed companies (McCahery and Vermeulen, 2010). Thus, there is a growing practical need for corporate governance tailored to small firms.

In contrast to the modern corporations with the large economy of scale and scope researched by Berle and Means (1932) or Chandler (1977), some researchers have predicted that small corporations are the future of all economies (Audretsch and Lehmann 2012). As Rajan and Zingales (2000) point out, small corporations are the backbone of any economy, the driving force in employment generation, the major contributor of exports, and the main innovators in research and development. Summarised below are the relevant theories on corporate governance, namely Agency Theory, Stakeholder Theory and Resource-dependency Theory.

\section{Agency Theory}

Agency theory is highly relevant to understanding corporate governance. Ross (1973) first formulated the Agency Theory Paradigm in the 1970s, identifying the principal problem. The term was first associated with agency costs by Jensen and Meckling in 1976 (Ross 1973; Jensen and Meckling 1976; Shapiro 2005). Rooted in Information Economics (Turnbull 1997), Agency Theory complements the risk sharing literature by including the agency problem that occurs when goals of cooperating parties differ (Ross 1973; Jensen and Meckling 1976). Using contracts as a metaphor, Agency Theory attempts to resolve two problems that may occur when one party (the principal) delegates work to 
another (agent). The first is the conflict of goals between the principal and agent and the costs associated with the minimisation of such discrepancy; the second is the problem of sharing risk when the risk preference of the principal and agent differs (Eisenhardt 1989).

The key idea of Agency Theory is that, as a solution to the "principal-agent" problem, contracts between principals and agents should reflect efficient organisation of information and risk-bearing costs. Agency Theory rests on a number of assumptions, including human assumptions of selfinterest, bounded rationality and risk aversion; organisational assumptions on partial goal conflict among participants, efficiency as the effectiveness criterion and information asymmetry between principal and agent; and information assumptions on information as a valuable commodity. The information asymmetry problem embedded in the principal-agency relationship may result in moral hazard and adverse selection and precludes cooperative parties from the benefits of sharing risks. Consequently, the ex-ante contracts between the principal and agent are incomplete. Agency Theory may be applied to any contractual relationships in which the principal and agent have partly differing goals and risk preferences, for example, compensation, regulation, leadership, impression management, whistle-blowing, vertical integration, merge \& acquisition, and transfer pricing (Eisenhardt 1989).

Agency Theory serves as the underlying rationale for corporate law as well as principles and regulations of corporate governance. These address three sets of principal-agency conflicts: (1) the shareholders and the management; (2) majority shareholders and minority shareholders; and (3) the controller of the company and non-shareholding stakeholders (Davies 2000).

For small firms, particularly for micro- businesses and family businesses, ownership and control are concentrated in the owner/manager's hands. Thus, corporate governance should address the latter two conflicts (Li 2014). The board's role of monitoring may not be as strong as it is expected in large companies, rather the board of directors should be used for resource purposes. Moreover, the board should be expected to protect minority shareholders and non-shareholding stakeholders (Corbetta and Salvato 2004).

\section{Stakeholder Theory}

Freeman (1984) identifies and models the groups who are stakeholders of a corporation. He also both describes and recommends methods by which management can give due regard to the interests of these groups. Freeman's initial objective was to develop a pragmatic approach to strategy which urges organizations to recognise the significance of stakeholders to achieve superior performance. Freeman drew on various pieces of literature to develop Stakeholder Theory including strategic management, corporate planning, systems theory and corporate social responsibility (Laplume, Sonpar et al. 2008). In short, it attempts to address whose stake counts in business decisions.

The theoretical foundation of the Stakeholder Theory is private ownership (Donaldson and Preston 1995). Freeman (2010) challenged the long-standing assumption in economics and management literature of the past two centuries that the objective of firms is to maximize shareholders' wealth. Rather, Freeman suggested that the firm's objective is to optimize stakeholders' wellbeing in order to create strategic advantage (Laplume, Sonpar et al. 2008). In Stakeholder Theory, a firm is assumed to be a business opportunity (Freeman, Harrison et al. 2010), which is fundamentally different from Friedman's treatment of business as markets and maximizing tools (Friedman 1970), Jensen and Meckling's move toward business as an agency (Jensen and Meckling 1976), Porter's perspective of business as a competitive strategy (Porter 1979), and Williamson's treatment of business as a nexus of transaction costs (1981).

\section{Propositions of Stakeholder Theory}

Freeman's Stakeholder Theory intends to address three problems: (1) the problem of value creation and trade; (2) the problem of the ethics of capitalism; and (3) the problem of a managerial mindset 
(Freeman et al. 2010). Freeman et al. (2010) holds that: (1) the basic objective of a firm is to create value for stakeholders; (2) business is a set of relationships among groups which have a stake in the business activities; (3) business is about how customers, suppliers, employees, financiers (such as stockholders, bondholders, banks, or investors), communities, and managers interact and create value. To understand a business is to know how these relationships work. In this context, the executive's or entrepreneur's job is to manage and shape these relationships. Hence, stakeholders are defined as customers, suppliers, employees, investors, communities, and managers who interact and create value for firms (Freeman, Harrison et al. 2010).

Stakeholder theory stresses the dependency of the firm on many different groups. It strongly suggests that corporations are influenced by loosely defined groups of people, each seeking something different from the organization. This theory identifies who benefits from a firm, as well as locates who, in fact, controls its corporate policy. The stakeholder view of strategy is an instrumental theory of the corporation, integrating both the resource-based view as well as the market-based view, and adding a socio-political level. This view of the firm is used to define the specific stakeholders of a corporation (the normative theory of stakeholder identification (Donaldson and Preston, 1995)) as well as examine the conditions under which these parties should be treated as stakeholders. The normative aspect and the descriptive aspect combined forms the modern treatment of Stakeholder Theory.

Donaldson and Preston (1995) argue that the normative base of the theory, including the "identification of moral or philosophical guidelines for the operation and management of the corporation", is the core of the theory. Mitchell et al. (2012) derive a typology of stakeholders based on the attributes of power (the extent a party has means to impose its will in a relationship), legitimacy (socially accepted and expected structures or behaviors), and urgency (time sensitivity or criticality of the stakeholder's claims). By examining the combination of these attributes in a binary manner, eight types of stakeholders are identified and described along with their implications for the organization. Friedman and Miles (2002) explore the implications of contentious relationships between stakeholders and organizations by introducing compatible/incompatible interests and necessary/contingent connections as additional attributes with which to examine the substance of these relationships.

\section{The Resource-dependency Theory}

Jeff Pfeffer's 1972 dissertation and prolific proceeding publications marked the birth of resource dependence theory. In 1978 Pfeffer and Salancik published The External Control of Organization, which pinpointed the "power-dependence relations" and led to the popularity of the resource dependent theory.

\section{Assumptions of Resource Dependence Theory}

The Resource Dependence Theory assumes that a firm's power over its external environment is critical to earning a competitive advantage for a firm. The external environment such as suppliers, customers and board of directors, are contingencies of the organisation's power. By applying multiple strategies, the firm is able to combat the contingencies and minimise uncertainty and interdependence on the environment (Hillman et al. 2009).

\section{Propositions of Resource Dependence Theory}

The Resource Dependence Theory has three major ideas: (1) external environment matters. The social context in which a business operates may have direct impact on resource allocation; (2) organisations should develop strategies to enhance their autonomy of acquiring and allocating resources with a view to improving the organisation performance. The process of seeking autonomy reduces the organisations' dependency on resources; and (3) market power is important for understanding internal and external actions of the organisation (Pfeffer 
1972). In particular, the emphasis on market power distinguishes resource dependence theory with other competing theories in explaining the firm's behaviour.

The resource dependence theory considers internal and external resources as major contingencies for organisational performance. The underlying assumption is that, though resource allocation can be planned there are uncertainties in the availability and cost of obtaining the resource related information. Hence, resources are critical to organisations. Resources may come from environments internal or external to the organisations. Internal resources may include input such as capital, labour and technology, management knowledge, production and marking capabilities, board of directors, employees' morale and satisfaction, the owners' family networks and managers' networks; external resources may include customers, investors, suppliers, competitors, regulators, community, and environment. The resources one organization needs are thus often in the hands of other organizations (Williams and McWilliams 2014). Such resources serve as a basis for market power, which enables one organisation to be dependent on each other, even though they are legally independent. Pfeffer (1972) also contends that the market power of an organisation and its dependence on resources are intertwined. Such powers are constrained by environmental contingencies and are potentially mutual to the two organisations which have the relationship.

Hillman et al. (2000) further argued that though resource contraints of an organisation may come from numerous sources such as labour, capital, raw material, board of directors, personal networks, and entrepreneurship, each resource does not have an equal weight on organisational performance. In addition, given that organisations face limited resources and tight budgets for accessing resource related information, they may not be able to use each resource contingent fairly. However, they must have the critical resources required to add value to an organization's core business in order to function. Thus organisations should identify critical resources and attend to them in order to achieve optimal performance.

The Resource Dependence Theory complements Agency Theory by arguing that the board of directors can be used as a mechanism to curb managerial self-servicing behaviour, but also, in the meantime serve as valuable resource for the organisation. Directors are selected based on a range of technical, interpersonal and conceptual skills, their motivation to manage, and their strong connections with the market, in particular, with the resources external to the organisation such as customers, suppliers and financers. Hence, the board of directors may serve as a nexus between the internal environment and external environment, which may further synergize internal and external resources. Furthermore, having more external directors sitting on the board may benefit the organisation in more ways than one. Though they may have less impact on key business decision making, their view as an independent voice, their role as an extra source to understand the customer's needs, and their capability of offering a balanced understanding of the potential social and economic impact of a business decision will add significant value to the organisations performance (Hillman and Dalziel 2003).

Based on the aforementioned three theories, the corporate governance of small corporations, as a latent variable, can be measured by board size, board independence, board meeting frequency, directors' use of their network, board interest alignment, succession planning and independent auditing ( $\mathrm{Li} 2014$ ). 


\section{The relationship between corporate governance and financial performance of small corporations in Australia}

Agency Theorists argued for a positive relationship between corporate governance and financial performance in organisations, while the Stakeholder Theorists proposed that performance may depend on managing different stakeholder interests. Resource Dependency theorists suggest that directors and their governance functions are among the resources of a firm.

The empirical literature on corporate governance is vast and are reviewed extensively by Shleifer and Vishny (1997), Zingales (1998), Tirole (2001), Denis (2001), Gillan (2006), Bebchuk and Weisbach (2010), Brown, Beekes, and Verhoeven (2010), Hermalin (2012) and Agrawal and Knoeber (2013). It is surprising that in the large body of literature reviewed in the abovementioned articles, corporate governance mechanisms were mainly treated as isolated mechanisms and small corporations were mainly overlooked.

Acknowledging that different corporate governance mechanisms may complement or substitute each other, the recent decade witnessed an increased interest by researchers to treat corporate governance mechanisms as a 'bundle' (Clarke and Branson 2012). This study responds to the call by treating corporate governance as a latent variable or a 'bundle'.

Given the predominance of the Agency Theory in corporate governance research, the null hypothesis of this study is that

H0: There is a positive relationship between corporate governance and financial performance of small corporations in Australia (Fig. 1).

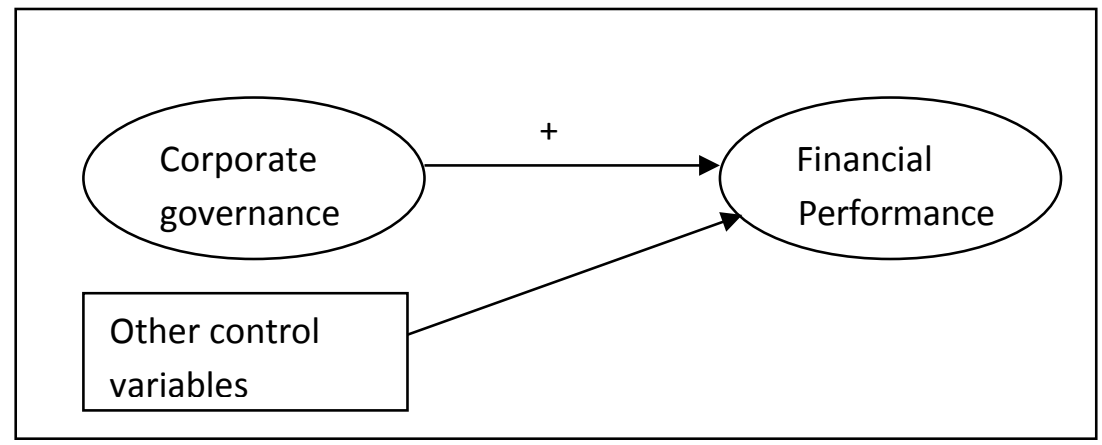

Figure 1 Conceptual framework on corporate governance and financial performance of small

corporations

\section{METHOD}

\section{Data collection}

An online survey using Survey Monkey, supported by small business associations that included COSBOA's (Coalition of Small Business Organisations of Australia) twenty six organisations resulted in a sample of 312 respondents.

\section{Measures}

Measures for corporate governance

Prior literature identifies eight main types of corporate governance mechanisms pertinent to small corporations, namely, board size, board independence, board interest alignment, meeting frequency, ownership structure, directors' network, succession planning, independent auditing (Gillan 2006). 


\section{Measures for financial performance}

Financial performance is measured by the accounting indicators of the firms, including return on assets (ROA), return on equity (ROE), return on investment (ROI), Tobin's Q, share price, operating cash flow, market-to-book ratio and R\&D spending (Orlitzky et al. 2003; van Essen et al. 2012).

\section{Small Business Corporate Governance Questionnaire}

Based on the measures of corporate governance and financial performance outlined above, the authors designed the Small Business Corporate Governance Questionnaire. The questionnaire captures data on corporate governance, including board of directors, board size, number of independent directors sitting on the board, sources of board of directors, number of board meetings hold each year, percentage of shares owned by the top five owners, extent to which directors use their personal and professional network for business development, succession planning and whether the small corporation is audited by independent auditors; and financial performance, including total assets, total sales, net profit and sales growth.

\section{Analytic techniques}

Structural equation modelling (SEM) was applied to empirically test the statistical hypothesis. The SEM is recognised in the field as an appropriate analytical approach for confirmative causal relationship analysis. Moreover, SEM can be viewed as an 'umbrella' tool encompassing a set of multivariate statistical approaches including conventional and recent development approaches. It is a widely used approach in social sciences because of its capacity to deal with latent variables.

\section{RESEARCH RESULTS}

\section{Measurement model of corporate governance}

Corporate governance was measured by seven indicators, namely board size, duality (the CEO is also chair of the board), board independence, interest alignment, meeting frequency, board network and independent audit (Fig. 2). The fit statistics indicate a satisfactory fit of the model specified in Fig. 2.

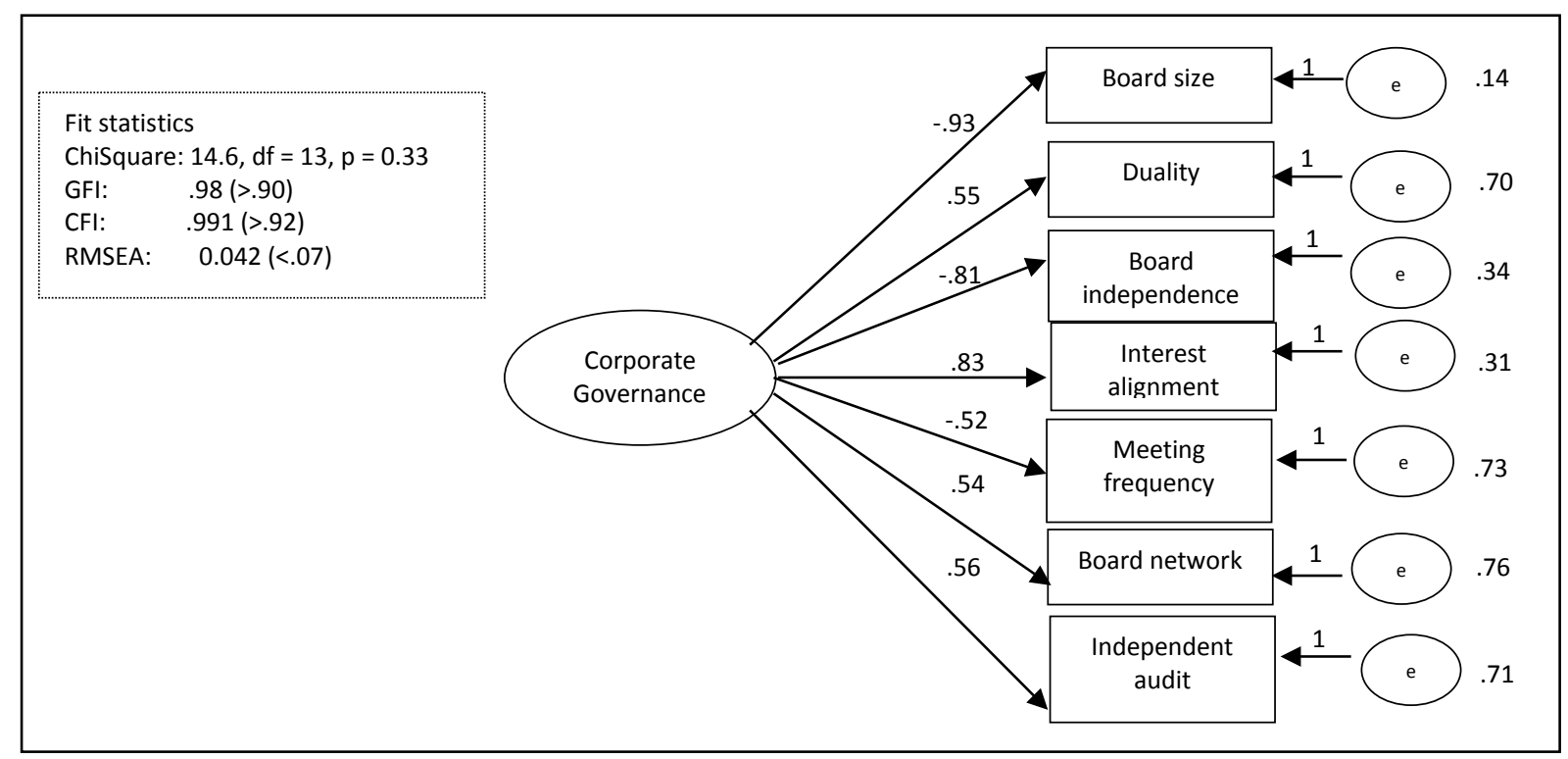

Figure 2: Measurement model of corporate governance 
Corporate governance is an unobserved construct and is thus enclosed by ovals. Seven measures (enclosed by rectangles) were specified, each with a nonzero loading on the factor was designed to measure, and zero loading on other factors. Thus each indicator was identified with a unique construct. Error variables (enclosed by ovals because they are not directly observed) represent a composite of any influences on the observed measures that are not measured in this study.

\section{Goodness of fit index}

There is 13 degree of freedom (the construct variance is not shown for visual clarity). Thus normed chi-square $=0.33$, GFI $=0.980, \mathrm{CFI}=0.991$ all suggested the model is plausible. The RMSEA index is acceptably low at 0.042 . As described in Chapter 6, a confidence interval provides a test of close fit (C.I. straddles 0.05), and not-close fit (entire C.I. lies above 0.05). Thus, for the financial performance measurement model, a hypothesis of close fit $<0.05$ was accepted, and not-close fit $<0.05$ was rejected. There was thus evidence to suggest that the financial performance measurement model had adequate overall goodness-of-fit.

\section{Construct validity}

The CFA provided a test of convergent validity for each of the sets of items that measured each construct. All path estimates were significant at the 1\% level, and loadings between measured variables and factors were generally greater than 0.5. Indicators loaded significantly on their hypothesized construct, indicating adequate levels of convergent validity (Barki and Hartwick 2001).

\section{Nested models to test dimensionality}

The plausibility of one dimension of corporate governance for small corporations (as opposed to, for example, a multiple dimension model) was assessed in a nested modelling process. A further test of the measurement model was made by comparing two nested models (Barki and Hartwick, 2003). The results showed that the corporate governance of small corporations is a uni-dimensional construct that can be measured by sever indicators, namely board size, duality (the CEO is also chair of the board), board independence, interest alignment, meeting frequency, board network and independent audit.

\section{Measurement model for financial performance}

Confirmatory factor analysis was performed where four measures of financial performance, namely total assets (assets), total sales (sales), net profit, and net profit growth derived from the abovementioned literature were allowed to correlate freely with each other but were uncorrelated with measurement errors from other indicators (Byrne 2010). The path diagram together with standardised parameter estimates is shown in Figure 3.

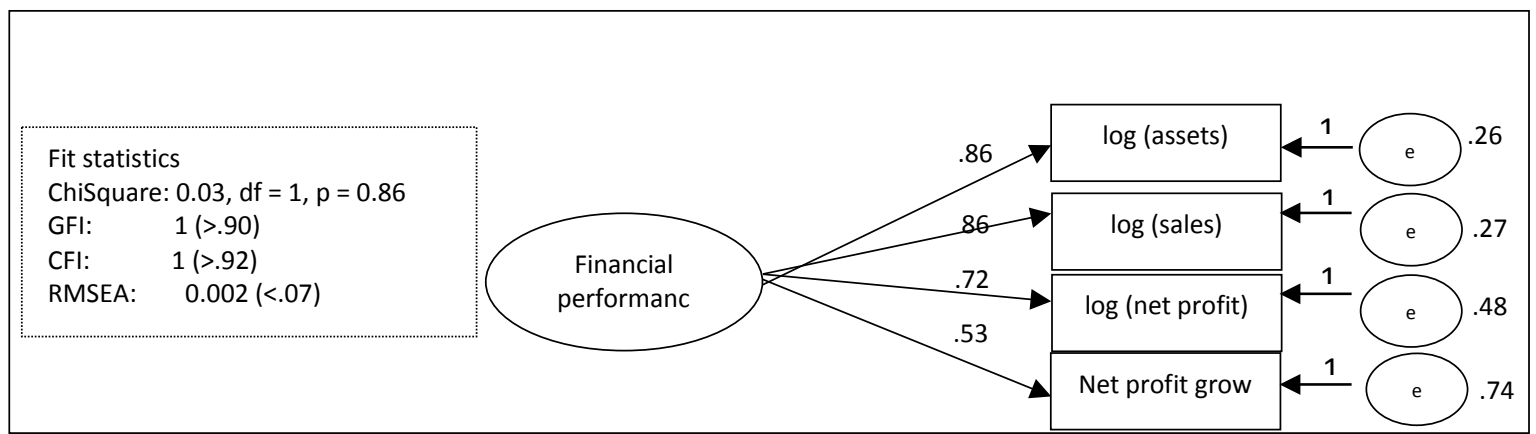

Figure 3: Measurement Model of Financial Performance

The measurement model (Figure 3) hypothesized that four hypothesized financial performance dimensions of namely total assets (assets), total sales (sales), net profit, and net profit growth were correlated. Included in the model was a factor measuring overall financial performance as perceived by the respondent. This is an unobserved construct and is thus enclosed by ovals. Goodness of fit scores and the unit dimensionality tests were applied in the same way as they were to corporate governance and the results passed the tests. 


\section{Hypothesis testing}

The measurement models for financial performance and corporate governance were specified in Fig. 3 and Fig. 2. The Structural Equation Model (SEM) was applied to assess the impact of corporate governance on small corporations' financial performance. The standardised SEM results indicate that corporate governance has a negative impact on the financial performance of small corporations. The standardised regression (which is also correlation) between the two latent variables - corporate governance and financial performance is -0.40 which is negative and statistically significant, meaning that firms with better corporate governance structure in place tends to perform worse in financial terms (Fig. 4). The fit indices indicate that the model is satisfactory in meeting the fit criteria for a SEM. 


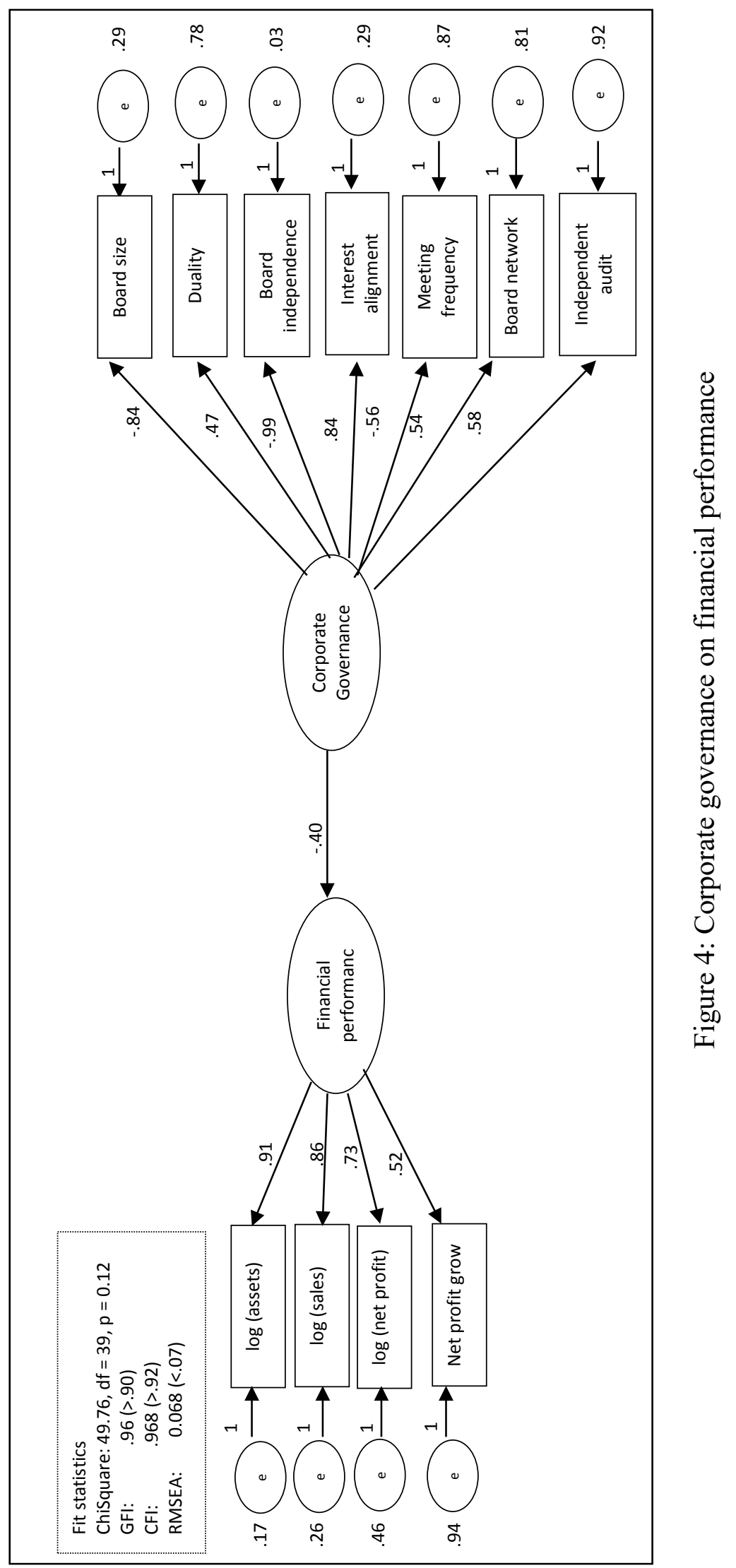




\section{DISCUSSION}

Empirical results from the SEM model in the result section found a negative impact of corporate governance on the financial performance of small corporations, which challenges the well-established theories on corporate governance in the large corporations' literature. The effect size is 0.4 , indicating a medium effect.

According to the Cadbury Report (1990) and the Organisation of Economic Co-operation and Development (OECD, 2004), corporations with sound governance systems yield good financial performance. The result from this study seems to contradict those in the well-cited literature of large corporations.

However, considering the disparities between small corporations and their larger counterparts, this result does not conflict with the existing literature, but complements them in four ways:

i. Though the literature is flooded with literature investigating the impact of a separate corporate governance mechanism on firm performance (Bhagat and Bolton 2008; Dalton et al. 1998; Zahra and Pearce 1989), treatment of corporate governance mechanisms as a bundle is fairly recent and is 'limited' (Hoskisson et al. 2009; Ward et al. 2009).

Ward et al. (2009) points out that governance mechanism may serve as either complements or substitutes to one another. Hence, the estimation of the overall effect requires the corporate governance mechanism to be treated as a bundle (Mock 2007). Moreover, there is still a dearth of research into corporate governance bundles in small corporations. The SEM is recognised as the one of the most common techniques to empirically analyse the corporate governance mechanism as a bundle - a latent construct which can be measured by its indicators (Bowen and Guo 2011).

This research project provides new evidence that the corporate governance bundle, measured by variables populated in the large corporations' literature, impedes the financial performance of small corporations. Why is this so? Admittedly, the literature has yet to provide evidencebased solutions for corporate governance in small corporations, with this study being the first to look into such issues. In addition, there may be three reasons, to be discussed below, the first reason is that the existing theory fails to consider the differences between large corporations and small corporations; the second reason is that small corporations are yet to incorporate governance practice in order to improve their financial performance, provided that the regulatory bodies are able to develop small corporations-tailored corporate governance guidelines; and, the third reason is that the same corporate governance, for instance, the board of directors, may play different roles in small corporations than their larger counterparts.

ii. The research finding of this project adds to the Agency Theory premise that multiple facets of the interest conflicts in the small corporations should be considered. Agency Theory has been used predominantly in justifying the existence of agency costs in large corporations between the owner and managers and in identifying ways to reduce it. Quite oppositely, small corporations do not have dispersed ownership structures and, consequently, the interest conflict between owner and managers is not the only major issue ( $\mathrm{Li}$ et al. 2013). The main interest conflicts are between the shareholders and the other stakeholders, between dominating owners and the other owner/managers, as well as between family owners and other types of owners. In this regard, the Stakeholder Theory may be more sensible to justify the importance of corporate governance issues in small corporations (Wright et al. 2013).

iii. Small corporations passively react to corporate governance related regulations. In the responses to the open-ended questions, small corporations' owner/managers point out that the ASIC regulation, in particular on director's duties and registration requirements are burdens to them, but with which they have to comply. Evidently, more discussion has yet to happen between the small corporations and ASIC in order to design small corporations-suited corporate governance practices in a view to improving their financial performance rather than compliance. 
iv. The results of this study call for an extended view about the role of the board of directors in a firm. A board's role in Agency Theory, Stakeholder Theory and Network Theory has been classified mainly as control and monitoring (Ingley and Karoui 2012). Boards in small corporations offer more than the controlling role, but also resource roles (Armstrong et al. 2012). Boards of directors also provide knowledge, skills, resource and social connections, which are all valuable assets to the financial performance of small corporations.

\section{STUDY LIMITATIONS AND FUTURE RESEARCH}

This study is subjected to the self-selection bias due to its use of the convenient online survey approach. Though the fact that the survey response rate is almost proportional to the distribution of small corporations by state, it may face the risk of violation of internal validity caused by failing to adopt a random sampling approach. Admittedly, a self-selection bias is always a challenge for any non-experimental types of research. A discussion of the specific consequences of self-selection bias can be found in Bethlehem and Biffignandi (2011). This study, however, made the effort to correct the self-selection bias by applying sampling weights matching the number of small and medium sized businesses in respective local government areas.

Future work could focus on complementing this study by adopting a more rigorous sampling approach, coupled with a finer level of quasi-experiment design, and may be used to collect more reliable information to represent the population. In addition, future research may also investigate the factors which mediates and moderates the relationship between corporate governance and financial performance in small corporations in depth.

\section{ACKNOWLEDGEMENT}

The authors would like to thank the support of an ARC Linkage Grant jointly funded by the ARC, Federal Department of Treasury and Council of Small Business of Australia (COSBOA) titled 'Developing a Responsive Regulatory System for Small Corporations in Australia'. The authors would like to extend their appreciation to the other members of the ARC Linkage team for their kind support. The errors incurred in the paper solely belong to the Authors.

\section{REFERENCES}

Adams, R. B., \& Ferreira, D. (2007). A theory of friendly boards. The Journal of Finance, 62(1), 217250.

Agrawal, A. and C.R. Knoeber (2013), "Corporate governance and firm performance", in C.R. Thomas and WilliamShughart II, editors, Oxford Handbook of Managerial Economics, Oxford University Press, New York.

Armstrong, A., Y., Li, A., Clarke, et al. (2011) Developing a Responsive Regulatory System for Australia's Small Corporations. Governance Program, Victoria Law School, Melbourne, Australia, ISBN: 978-1-86272-692-5.

Armstrong, Li and Clarke et al. (2012). Victoria University (VU) Small Corporations Regulation Survey 2012. Unpublished.Weblink: http://www.surveymonkey.com/s/GJTNGDR.

Audretsch, D. B., \& Lehmann, E. (Eds.). (2011). Corporate Governance in Small and Medium-Sized firms. Edward Elgar.

Ayotte K. M., E.S. Hotchkiss \& K. S. Thorburn (2012) Governance in Financial Distress and Bankruptcy. The Oxford Handbook of Corporate Governance, 421.

Barki, H., \& Hartwick, J. (2001). Interpersonal conflict and its management in information system development. Mis Quarterly, 195-228.Barki and Hartwick, 2003

Bebchuk, L.A. and M.S. Weisbach (2010), "The state of corporate governance research", Review of Financial Studies, 23, 939-961.

Bertoni, F. A. B. I. O., Colombo, M. G., \& Croce, A. N. N. A. L. I. S. A. (2013). Corporate governance in high-tech firms. The Oxford handbook of corporate governance, 365. 
Bethlehem, J., \& Biffignandi, S. (2011). Handbook of web surveys (Vol. 567). John Wiley \& Sons.

Bhagat, S. and B. Bolton (2008). "Corporate governance and firm performance." Journal of Corporate Finance 14(3): 257-273.

Bowen, N. K., \& Guo, S. (2011). Structural equation modeling. Oxford University Press.

Brown, Ph., W. Beekes, and P. Verhoeven (2010), "Corporate governance, accounting and finance: A review", Accounting \& Finance, 51, 96-172.

Byrne, B M (2010) Structural Equation Modelling with AMOS: basic concepts, applications and programming, 2nd edition, Lawrence Erlbaum Associates, London.Cadbury Report (1990)

Clarke, T., \& Branson, D. M. (Eds.). (2012). The SAGE handbook of corporate governance. SAGE Publications.

Dalton, D. R., C. M. Daily, et al. (1998). "Meta-analytic reviews of board composition, leadership structure, and financial performance." Strategic Management Journal 19(3): 269-290.

Du Plessis, J. J., M. Bagaric, et al. (2010). Principles of contemporary corporate governance, Cambridge Univ Pr.

Filatotchev, I., \& Allcock, D. (2012). Corporate Governance in IPOS. The Oxford Handbook of Corporate Governance, 421.

Freeman, R. E., J. S. Harrison, et al. (2010). Stakeholder theory: The state of the art, Cambridge Univ Pr.

Gillan, S.L. (2006), "Recent developments in corporate governance: An overview", Journal of Corporate Finance, 12, 381-402.

Gillan, S.L. (2006). "Recent developments in corporate governance: An overview", Journal of Corporate Finance, 12, 381-402.

Hermalin, B. (2012), "Corporate governance: a critical appraisal", in R. Gibbons and J. Roberts, editors, Handbook of Organizational Economics, Princeton University Press,

Hoskisson, R. E., M. W. Castleton, et al. (2009). "Complementarity in Monitoring and Bonding: More Intense Monitoring Leads to Higher Executive Compensation." Academy of Management Perspectives 23(2): 57-74.

Jensen, M. C. and W. H. Meckling (1976). "Theory of the firm: Managerial behavior, agency costs and ownership structure." Journal of Financial Economics 3(4): 305-360.

Karoui, L., Ingley, C., \& Khlif, W. (2012). Enhancing the Board's Monitoring Performance in SMEs. Board Directors and Corporate Social Responsibility, 60.

Li, Y., W., Dai, A., Armstrong, A., Clarke and M., Du (in press) (2013). Developing an Integrated Supply Chain Solution to Small Businesses in Australia. International Journal of High Performance Computing and Networking.

MOCK, T. J., STROHM, C., \& SWARTZ, K. M. (2007). An examination of worldwide assured sustainability reporting. Australian Accounting Review, 17(41), 67-77.

OECD (2004). OECD Principles of Corporate Governance.

OECD (2012) Corporate Governance, Value Creation and Growth. Accessed on February 2nd 2013 via http://www.oecd.org/corporate/ca/corporategovernanceprinciples/50242938.pdf.

Orlitzky, M, Schmidt, FL and Rynes, SL (2003). "Corporate social and financial performance: A meta-analysis", Organization Studies, vol. 24, no. 3, pp. 403-41.

Perry, M. (2012). Small firms and network economies. Routledge.

Shleifer, A., \& Vishny, R. W. (1997). A survey of corporate governance. The journal of finance, 52(2), 737-783.Zingales (1998),

Street, C. T., \& Cameron, A. F. (2007). External relationships and the small business: A review of small business alliance and network research. Journal of Small Business Management, 45(2), 239266.

Tirole, J. (2001), “Corporate governance”, Econometrica, 69, 1-35.Denis (2001),

Toms, S., \& Wilson, J. F. (2012). 22 Revisiting Chandler on the theory of the firm. Handbook on the Economics and Theory of the Firm, 297.

Uhlaner, L. M., F. W. Kellermanns, et al. (2012). "The entrepreneuring family: a new paradigm for family business research." Small Business Economics 38(1): 1-11.

van Essen, M., J. Oosterhout, et al. (2012). "Corporate boards and the performance of Asian firms: A meta-analysis." Asia Pacific Journal of Management. 
Ward, A. J., Brown, J. A., \& Rodriguez, D. (2009). Governance bundles, firm performance, and the substitutability and complementarity of governance mechanisms. Corporate Governance: An International Review, 17(5), 646-660.

Wright, M., Siegel, D. S., Keasey, K., \& Filatotchev, I. (Eds.). (2013). The Oxford handbook of corporate governance. Oxford University Press.

Wu, D. W. \& L. Tihanyi (2012) Corporate Governance in IPOS. The Oxford Handbook of Corporate Governance, 421.

Yiu, D.W., X. Chen \& Y., Xu (2012) Corporate Governance in Business Groups. The Oxford Handbook of Corporate Governance, 421.

Zahra, S. A. and J. A. Pearce Ii (1989). "Boards of Directors and Corporate Financial Performance: A Review and Integrative Model." Journal of Management 15(2): 291-334. 
